\title{
Pengaruh Waktu Pembenaman Pupuk Hijau dan Aplikasi Pupuk Organik Cair Terhadap Pertumbuhan dan Hasil Bawang Putih Siung Tunggal (Allium sativum, L.)
}

\author{
Albertus Nufa Sasi ${ }^{\mathrm{a}}$ \\ ${ }^{a}$ Fakultas Pertanian, Universitas Timor, Kefamenanu, TTU - NTT, 85613, Indonesia.
}

\section{Article Info}

Article histor

Received 14 September 2015

Received in revised form 20 September 2015

Accepted 18 Oktober 2015

\section{Keywords:}

Pupuk Hijau

Pupuk Organik Cair

Bawang Putih

\begin{abstract}
Abstrak
Penelitian ini bertujuan untuk mengetahui pengaruh waktu pembenaman pupuk hijau dan aplikasi pupuk organik cair terhadap pertumbuhan dan hasil bawang putih siung tunggal dengan mengunakan Rancangan Acak Kelompok (RAK) faktorial yang diulang tiga kali. Faktor pertama adalah waktu pembenaman pupuk hijau yang terdiri dari empat aras yaitu tanpa pembenaman pupuk hijau, -7 HST, 14 HST dan -21 HST. Faktor kedua adalah waktu aplikasi pupuk organik cair yang terdiri dari empat aras yaitu tanpa penyiraman pupuk organik cair, 15 HST, 30 HST dan 45 HST. Hasil penelitian menunjukkan bahwa interaksi antara waktu pembenaman pupuk hijau dan aplikasi pupuk organik cair hanya terjadi terhadap luas daun. Secara umum pembenaman pembenaman pupuk hijau berpengaruh nyata terhadap suhu tanah $50 \mathrm{HST}$, tinggi tanaman setiap waktu pengamatan, berat kering umbi per tanaman maupun per petak, berat siung tunggal per petak, persentase siung tunggal per petak dan indeks panen tetapi penerapan waktu pembenaman pupuk hijau yang berbeda hanya berpengaruh nyata terhadap tinggi tanaman 25 HST, sedangkan waktu aplikasi pupuk organik cair hanya berpengaruh nyata terhadap suhu tanah 50 HST. Pembenaman pupuk hijau pada -14 HST memberikan hasil panen tertinggi yakni 4,99 t/ha. Aplikasi pupuk organik cair pada 45 HST memberikan hasil panen tertinggi yaitu 3,95 t/ha. (O2016 dipublikasikan oleh Savana Cendana.
\end{abstract}

\section{Pendahuluan}

Bawang putih (Allium sativum, L.) merupakan komoditas sayuran yang banyak mendatangkan keuntungan karena memiliki nilai ekonomi tinggi. Bawang putih adalah salah satu komoditas hortikultura yang digunakan sebagai bumbu masakan hampir setiap masakan di Indonesia. Serta manfaa lain dari bawang putih dalam dunia kesehatan, seperti mengobati penyakit kulit dan beberapa hal lainnya (Santoso, 1988).

Komponen utama umbi bawang putih tidak berbau disebut komplek sativumin, yang diabsorbsi oleh glukosa dalam bentuk aslinya untuk mencegah proses dekomposisi. Dekomposisi kompleks sativumin ini menghasilkan bau khas yang tidak sedap dari allyl sulfide, allyl disulfate, allyl mercaptane, alun allicin dan alliin. Komponen kimia ini mengandung sulfur. Sulfur merupakan komponen penting yang terkandung dalam bawang putih. Adapun komponen aktif bawang putih sativumin adalah allicin, scordinine glycoside, scormine, thiocornim, scordinine A dan B, creatinine, methionine, homocystein, vitamin $\mathrm{B}$, vitamin $\mathrm{C}$, methionine dan organik germanium yang masing-masing mempunyai kegunaan berbeda (Anantyo, 2009).

Indonesia merupakan negara penghasil bawang, baik itu bawang merah maupun bawang putih. Namun nilai impor yang ditunjukan dalam beberapa tahun belakangan ini terhadap komoditas bawang merah dan bawang putih cukup tinggi. Data produksi bawang putih dari tahun 2009 hingga 2013 berturut-turut adalah $17.313,12.339,15.419,12.295$ dan 14.749 ton. Impo bawang putih pada bulan Januari 2013 mencapai 23.000 ton. Produksi bawang putih dalam negeri hanya bisa memenuhi 5\% dari kebutuhan nasional, sedangkan 95\% kekurangannya masih dipenuhi oleh impor. Berbeda halnya dengan keadaan komoditas bawang merah di Indonesia (BPS RI, 2014).

Bawang putih di Kabupaten Timor Tengah Utara (TTU) mempunyai nilai ekonomis yang cukup tinggi, sehingga dikelompokkan menjadi komoditas unggulan yang dapat mendongkrak nilai ekonomi dan pendapatan masyarakat Data produksi bawang putih di Kabupaten TTU dari tahun 2007 hingga 2010 mengalami fluktuasi produksi. Pada tahun 2007 produksi bawang putih sebesar 80 ton, namun mengalami penurunan hingga 12 ton pada tahun 2010 (BPS Kab TTU, 2011).

Beberapa penyebab rendahnya produksi bawang putih adalah teknik budidaya yang kurang optimal, kualitas bibit yang rendah, serangan penyakit terutama jamur dan virus, lingkungan tumbuh yang kurang optimum serta tingginya kehilangan hasil akibat teknik penyimpanan umbi yang kurang memadai pada tingkat petani (Hilman, 1994). Peningkatan produksi bawang putih dapat dilakukan dengan perbaikan teknik budidaya diantaranya adalah aplikasi pemupukan yang tepat.

Pupuk hijau adalah pupuk organik yang berasal dari tanaman atau berupa sisa panen. Bahan tanaman ini dapat dibenamkan pada waktu masih hijau atau setelah dikomposkan. Sumber pupuk hijau dapat berupa sisa-sisa tanaman (sisa panen) atau tanaman yang ditanam secara khusus sebagai penghasil pupuk hijau, seperti sisa-sisa tanaman, kacang-kacangan dan tanaman paku ai (Azolla). Jenis tanaman yang dijadikan sumber pupuk hijau diutamakan dari jenis legume, karena tanaman ini mengandung hara yang relatif tinggi, terutama nitrogen dibandingkan dengan jenis tanaman lainnya. Tanaman legume juga relatif mudah terdekomposisi sehingga penyediaan haranya menjadi lebih cepat Pupuk organik cair merupakan salah satu jenis pupuk yang dapat diaplikasikan ke tanaman. Pupuk organik cair kebanyakan diaplikasikan melalui hijauan daun atau disebut sebagai pupuk cair foliar yang mengandung hara makro dan mikro esensial (N, P, K, S, Ca, Mg, B, Mo, Cu, Fe, Mn, dan bahan organik). Pupuk organik cair selain dapat memperbaiki sifat fisik, kimia, dan biologi tanah, juga membantu meningkatkan produksi tanaman, meningkatkan kualitas produk tanaman, mengurangi penggunaan pupuk anorganik dan sebagai alternatif pengganti pupuk kandang (Parman, 2007). Berdasarkan beberapa hasi penelitian menunjukkan bahwa pemberian pupuk organik cair melalui daun memberikan pertumbuhan dan hasil tanaman yang lebih baik dari pada pemberian melalui tanah (Rahmi and Jumiati, 2007).

Berdasarkan uraian tersebut di atas maka perlu dilakukan penelitian dengan judul pengaruh waktu pembenaman pupuk hijau dan penyiraman pupuk organik cair terhadap pertumbuhan dan hasil bawang putih siung tunggal. Penelitian ini bertujuan untuk mengetahui pengaruh waktu pembenaman pupuk hijau dan aplikasi pupuk organik cair terhadap pertumbuhan dan hasil bawang putih siung tunggal.

\section{Metode}

2.1 Waktu dan Tempat

Penelitian ini dilaksanakan pada bulan Mei sampai September di kebun percobaan Fakultas Pertanian, Universitas Timor Kelurahan Sasi, Kecamatan Kota Kefamenanu, Kabupaten TTU. Topografi berbukit-bukit dengan ketinggian $\pm 400 \mathrm{~m} \mathrm{dpl}$, curah hujan $900-1.500 \mathrm{~mm}$ per tahun, suhu udara berkisar antara $27^{\circ} \mathrm{C}$ dan $\mathrm{pH}$ tanah netral (6,5) (BPS Kab. TTU, 2007).

\subsection{Rancangan Percobaan}

Penelitian mengunakan Rancangan Acak Kelompok (RAK) faktorial 4 x 4 yang diulang tiga kali. Faktor pertama adalah waktu pembenaman pupuk hijau (P) yang terdiri dari empat aras yaitu tanpa pembenaman pupuk hijau $\left(\mathrm{p}_{0}\right),-7$ HST $\left(\mathrm{p}_{1}\right),-14 \operatorname{HST}\left(\mathrm{p}_{2}\right)$ dan -21 HST $\left(\mathrm{p}_{3}\right)$. Faktor kedua adalah waktu aplikasi pupuk organik cair $(\mathrm{T})$ yang terdiri dari empat aras yaitu tanpa penyiraman pupuk organik cair $\left(\mathrm{t}_{0}\right), 15 \mathrm{HST}\left(\mathrm{t}_{1}\right), 30 \mathrm{HST}\left(\mathrm{t}_{2}\right)$ dan $45 \mathrm{HST}\left(\mathrm{t}_{3}\right)$. Kombinasi perlakuannya adalah $\mathrm{p}_{0} \mathrm{t}_{0}, \mathrm{p}_{0} \mathrm{t}_{1}, \mathrm{p}_{0} \mathrm{t}_{2}, \mathrm{p}_{0} \mathrm{t}_{3}, \mathrm{p}_{1} \mathrm{t}_{0}, \mathrm{p}_{1} \mathrm{t}_{1}, \mathrm{p}_{1} \mathrm{t}_{2}, \mathrm{p}_{1} \mathrm{t}_{3}, \mathrm{p}_{2} \mathrm{t}_{0}, \mathrm{p}_{2} \mathrm{t}_{1}, \mathrm{p}_{2} \mathrm{t}_{2}, \mathrm{p}_{2} \mathrm{t}_{3}$, $\mathrm{p}_{3} \mathrm{t}_{0}, \mathrm{p}_{3} \mathrm{t}_{1}, \mathrm{p}_{3} \mathrm{t}_{2}$ dan $\mathrm{p}_{3} \mathrm{t}_{3}$

\subsection{Pelaksanaan Penelitian}

\section{a. Persiapan Benih}

Benih bawang putih yang digunakan dalam penelitian ini adalah, bawang yang berasal dari petani di Desa Noepesu, Kecamatan Miomaffo Barat, Kabupaten TTU. Terlebih dahulu telah dilakukan seleksi kemurnian benihnya dengan cara dipilih harus sehat dan besarnya seragam, warna kulit putih bersih umbi besar dan terhindar dari hama atau penyakit. Benih yang dibutuhkan dalam penelitian ini sebanyak 3.888 siung dengan benih cadangan sebanyak 5\% sehingga jumlah benih yang disiapkan sebanyak 4.083 siung.

b. Pengolahan Tanah

Lahan atau areal yang telah diukur dan dibersihkan dari gulma-gulma dan sisa-sisa tanaman yang ada. Pembersihan lahan dilakukan dengan menggunakan linggis, parang dan cangkul. Pengolahan tanah dilakukan dengan menggunakan cangkul, kemudian dilanjutkan dengan penggemburan tanah. Lahan yang digunakan berukuran panjang $16,5 \mathrm{~m}$ dan lebar 4,5 $\mathrm{m}$ dengan luas $74,25 \mathrm{~m}^{2}$ Lahan dibagi dalam tiga blok dan pada masing-masing blok dibuat 12 petak percobaan dengan ukuran panjang $1 \mathrm{~m}$ dan lebar $1 \mathrm{~m}$ sehingga secara keseluruhan terdapat 48 petak. Jarak antara petak $30 \mathrm{~cm}$ dan jarak antara blok $60 \mathrm{~cm}$. Pada setiap blok, petak dan tanaman sampel diberikan label menggunakan tiang bambu dan seng.

c. Pembuatan dan Pembenaman Pupuk Hijau

Bahan yang digunakan untuk pembuatan pupuk hijau adalah daun hijau (gamal), dedak halus, EM-4 dan air. Daun gamal dicampur merata dengan dedak halus, kemudian campurkan EM-4 dengan ukuran satu tutupan botol EM-4 untuk satu liter air percik pada campuran daun gamal dan dedak dambil diaduk sampai merata, kemudian ditumpuk sampai ketinggian antara $10-15 \mathrm{~cm}$ dan tutup rapat dengan karung. Dalam waktu 3-4 hari pupuk hijau telah jadi dan siap digunakan. Pemberian pupuk hijau dilakukan dengan cara pembenaman pada tanah menggunakan dosis $10 \mathrm{t} / \mathrm{ha}$ atau $1,125 \mathrm{~kg}$ per petak. Waktu aplikasi disesuaikan dengan perlakuan yaitu pada 12 petak tidak dibenamkan pupuk hijau, pada 12 petak dibenamkan pupuk hijau pada saat -7 HST, pada 12 petak 
dibenamkan pupuk hijau pada saat -14 HST dan pada 12 petak dibenamkan pupuk hijau pada saat -21 HST. Total kebutuhan pupuk sebanyak $54 \mathrm{~kg}$.

d. Penanaman

Penanaman dilakukan pada saat sore hari, dengan cara tugal sedalam \pm 3 $\mathrm{cm}$. Benih ditanam satu siung per lubang tanam kemudian ditutup dengan tanah. Jarak tanam yang digunakan adalah $10 \times 10 \mathrm{~cm}$. Jumlah tanaman dalam setiap petak adalah 81 tanaman dengan jumlah keseluruhan 3.888 tanaman.

e. Pembuatan dan Penyiraman Pupuk Organik Cair

Bahan yang digunakan untuk pembuatan pupuk cair adalah daun gamal, cirit sapi, EM-4 dan air. Langkah pertama, masukan kotoran ternak segar ke dalam drum sebagai dasar. Pastikan drum yang dipakai bisa ditutup rapat. Daun-daun dipotong-potong atau dicacah dengan ukuran kurang lebih $5 \mathrm{~cm}$ kemudian campurkan ke dalam drum yang sudah terisi air dan kotoran ternak. Tambahkan EM-4 dengan perbandingan yang sama, kemudian tuangkan ke dalam drum. Aduk secara perlahan-lahan sampai merata. Tutup rapat dan letakan ditempat yang teduh. Proses selanjutnya diamkan selama 3 minggu, sebelum pupuk organik cair digunakan, setiap tujuh hari penutup dibuka sedikit selama 5-10 menit, setelah itu ditutup kembali. Setelah itu pupuk organik cair siap digunakan. Aplikasi pupuk cair dilakukan dengan cara penyiraman menggunakan gembor menggunakan dosis 10 liter/ha atau 1,125 liter per petak. Waktu aplikasi disesuaikan dengan perlakuan yaitu sembilan petak pada saat 15 HST, sembilan petak pada saat $30 \mathrm{HST}$ dan sembilan petak pada saat 45 HST. Total kebutuhan pupuk cair sebanyak 54 liter.

f. Pemeliharaan

Pemeliharaan meliputi penyiraman, penyulaman, penyiangan serta pengendalian hama dan penyakit tanaman. Penyiraman dilakukan menggunakan gembor pada pagi dan sore hari. Penyulaman tidak dilakukan selama penelitian karena semua benih yang ditanam tumbuh atau tidak mengalami kerusakan. Penyiangan terhadap gulma dilakukan dengan mencabutnya dan dibantu dengan alat pencungkil, namun dilakukan hati-hati agar jangan sampai akar tanaman terganggu. Tanaman sempat mengalami gejala klorosis pada umur 30 HST, pengendalian dilakukan dengan cara penyemprotan Dithane M-45.

\section{g. Panen}

Tanaman bawang putih dipanen pada umur 90 HST dengan ciri-ciri pangkalan daun sudah lemas, daun berwarna kuning, umbi penuh dan kompak, sebagian umbi muncul ke permukaan tanah. Panen dilakukan dengan cara mencabut per tanaman.

\subsection{Parameter Pengamatan}

a. Tinggi Tanaman $(\mathrm{cm})$

Tinggi tanaman diukur dari pangkal batang sampai ujung daun paling tinggi, pengukuran menggunakan pengaris centimeter. Pengukuran dilakukan pada lima tanaman sampel saat berumur 25 HST, 50 HST dan 75 HST.

b. Luas Daun $\left(\mathrm{cm}^{2}\right)$

Luas daun diukur pada saat tanaman mencapai pertumbuhan vegetatif maksimum (50 HST). Pengukuran luas daun dilakukan menggunakan metode fotografi dengan cara mengambil semua daun pada tiga tanaman korban pada tiap petak, kemudian daun dipotret menggunakan kamera digital. Luas area daun kemudian dihitung menggunakan program ImageJ versi 1.41 o

c. Berat Kering Umbi Per Tanaman $(\mathrm{g})$

Berat kering umbi per tanaman diukur dengan cara menimbang berat kering umbi bawang lima tanaman sampel dalam tiap petak yang telah dikeringkan dengan cara dijemur selama satu minggu.

d. Berat Kering Umbi Per Petak (t/ha)

Berat kering umbi per petak diukur dengan cara menimbang berat kering umbi bawang setiap petak yang telah dikeringkan dengan cara dijemur selama satu minggu kemudian dikonversi ke t/ha.

e. Berat Siung Tunggal Per Petak (t/ha)

Berat siung tunggal per petak diukur dengan cara menimbang berat semua siung tunggal yang terbentuk dalam setiap petak yang telah dikeringkan dengan cara dijemur selama satu minggu kemudian dikonversi ke t/ha.

f. Persentase Siung Tunggal Per Petak (\%)

Persentase siung tunggal dihitung dengan cara membandingkan berat siung tunggal per petak dengan berat kering umbi per petak kemudian dikonversikan ke satuan $\%$. Persentase siung tunggal dihitung dengan rumus.

$$
\% \text { Siung Tunggal }=\frac{\text { Berat Siung Tunggal }}{\text { Berat Kering Umbi }} \times 100 \%
$$

\section{g. Berat Kering Berangkasan(t/ha)}

Berat kering berangkasan diukur dengan cara menimbang berangkasan semua tanaman dalam setiap petak yang telah dipanen dan dijemur selama satu minggu kemudian dikonversikan ke satuan t/ha.

h. Indeks Panen (\%)

Indeks panen dihitung dengan cara membandingkan berat bagian tanaman yang bernilai ekonomis dengan berat bagian seluruh tanaman kemudian dikonversikan ke satuan \%. Indeks panen dihitung dengan rumus.

$$
\mathrm{IP}=\frac{\mathrm{A}}{\mathrm{A}+\mathrm{B}} \mathrm{X} 100 \%
$$

\section{Keterangan \\ IP : Indeks Panen (\%) \\ A : : Berat Kering Umbi Per Petak (t/ha) \\ B : Berat Kering Brangkasan (t/ha)}

\subsection{Analisis Data}

Data hasil pengamatan kemudian dianalisis dengan menggunakan sidik ragam (Anova) Rancangan Acak Kelompok (RAK). Rata-rata perlakuan selanjutnya diuji lanjut dengan menggunakan Duncan Multiple Range Test (DMRT) dengan tingkat signifikasi 5\% sesuai petunjuk Gomez and Gomez, (1984). Analisis data menggunakan program SAS 9.1.

\section{Hasil dan Pembahasan}

\subsection{Tinggi Tanaman}

Hasil sidik ragam (Anova) menunjukkan tidak terjadi pengaruh interaksi antara waktu pembenaman pupuk hijau dan aplikasi pupuk organik cair terhadap tinggi tanaman.

\begin{tabular}{|c|c|c|c|c|c|c|}
\hline \multirow{2}{*}{$\begin{array}{c}\text { Umur } \\
\text { Tanaman }\end{array}$} & \multirow{2}{*}{$\begin{array}{l}\text { Waktu } \\
\text { Benam }\end{array}$} & \multicolumn{4}{|c|}{ Waktu Aplikasi Pupuk } & \multirow[b]{2}{*}{ Rerata } \\
\hline & & Kontrol & $15 \mathrm{HST}$ & $30 \mathrm{HST}$ & $45 \mathrm{HST}$ & \\
\hline \multirow{5}{*}{$25 \mathrm{HST}$} & Kontrol & 25,0 & 25,6 & 26,3 & 24,2 & $25,3 \mathrm{~b}$ \\
\hline & -7 HST & 24,2 & 26,3 & 25,2 & 22,7 & $24,6 \mathrm{~b}$ \\
\hline & -14 HST & 30,6 & 29,5 & 28,6 & 28,3 & $29,2 \mathrm{a}$ \\
\hline & $-21 \mathrm{HST}$ & 30,4 & 31,4 & 29,8 & 30,8 & $30,6 \mathrm{a}$ \\
\hline & Rerata & $27,5 \mathrm{a}$ & $28,2 \mathrm{a}$ & $27,5 \mathrm{a}$ & $26,5 \mathrm{a}$ & $(-)$ \\
\hline \multirow{5}{*}{$50 \mathrm{HST}$} & Kontrol & 36,3 & 38,7 & 39,3 & 34,6 & $37,2 \mathrm{~b}$ \\
\hline & $-7 \mathrm{HST}$ & 42,1 & 43,0 & 45,1 & 42,7 & $43,2 \mathrm{a}$ \\
\hline & -14 HST & 46,7 & 45,9 & 44,6 & 44,2 & $45,4 \mathrm{a}$ \\
\hline & $-21 \mathrm{HST}$ & 47,5 & 49,3 & 43,3 & 44,5 & $46,2 \mathrm{a}$ \\
\hline & Rerata & $43,1 \mathrm{a}$ & $44,2 \mathrm{a}$ & $43,1 \mathrm{a}$ & $41,5 \mathrm{a}$ & $(-)$ \\
\hline \multirow{5}{*}{75 HST } & Kontrol & 38,4 & 46,0 & 42,6 & 35,6 & $40,7 \mathrm{~b}$ \\
\hline & -7 HST & 46,5 & 46,5 & 48,6 & 45,3 & $46,7 \mathrm{a}$ \\
\hline & -14 HST & 50,8 & 49,0 & 50,7 & 48,1 & $49,6 \mathrm{a}$ \\
\hline & $-21 \mathrm{HST}$ & 50,7 & 51,1 & 46,7 & 47,1 & $48,9 \mathrm{a}$ \\
\hline & Rerata & $46,6 \mathrm{a}$ & $48,2 \mathrm{a}$ & $47,2 \mathrm{a}$ & $44,0 \mathrm{a}$ & $(-)$ \\
\hline & & & & & & \\
\hline
\end{tabular}

\section{Tabel 1. Tinggi Tanaman $(\mathrm{cm})$}

Waktu pembenaman pupuk hijau berpengaruh nyata terhadap tinggi tanaman saat pengamatan 25 HST dimana tanaman yang ditanam pada petak dengan pembenaman pupuk hijau saat -21 HST paling tinggi dan berbeda nyata dengan tinggi tanaman yang ditanam pada petak yang tidak dibenamkan pupuk hijau dan petak dengan pembenaman pupuk hijau pada -14 HST tetapi tidak berbeda nyata dengan tinggi tanaman yang ditanam pada petak dengan pembenaman pupuk hijau pada -14 HST. Pada pengamatan selanjutnya, bawang putih yang ditanam pada petak dengan pembenaman pupuk hijau secara umum lebih tinggi dan berbeda nyata dengan tinggi tanaman bawang putih yang ditanam pada petak yang tidak dibenamkan pupuk hijau, tetapi penerapan waktu pembenaman pupuk hijau yang berbeda tidak memberikan perberbedaan tinggi tanaman yang nyata walaupun tanaman yang ditanam pada petak dengan pembenaman pupuk hijau pada -21 HST cenderung lebih tinggi saat pengamatan 50 HST dan tanaman yang ditanam pada petak dengan pembenaman pupuk hijau pada -14 HST cenderung lebih tinggi saat pengamatan 75 HST.

Waktu aplikasi pupuk organik cair tidak berpengaruh nyata terhadap tinggi tanaman setiap waktu pengamatan tetapi data Tabel 1 . menunjukkan bahwa tanaman yang diberikan pupuk organik cair pada 15 HST selalu cenderung lebih tinggi sedangkan tanaman yang diberikan pupuk organik cair pada 45 HST selalu paling pendek.

\subsection{Luas Daun}

Hasil sidik ragam (Anova) menunjukkan terjadi pengaruh interaksi antara waktu pembenaman pupuk hijau dan aplikasi pupuk organik cair terhadap luas daun dimana permukaan daun bawang putih yang ditanam pada petak yang dibenamkan pupuk hijau saat -14 HST dan tidak diberikan pupuk organik cair paling luas yang tidak berbeda nyata dengan luas daun bawang putih yang ditanam pada petak yang dibenamkan pupuk hijau saat -21 HST kemudian diberikan pupuk organik cair saat 15 HST tetapi berbeda nyata dengan luas daun bawang putih yang diberikan kombinasi perlakuan yang lainnya.

Waktu pembenaman pupuk hijau tidak berpengaruh nyata terhadap luas daun tetapi data Tabel 2. menunjukkan bahwa permukaan daun dari tanaman yang ditanam pada petak yang tidak dibenamkan pupuk hijau cenderung lebih luas sedangkan permukaan daun dari tanaman yang ditanam pada petak dengan pembenaman pupuk hijau pada -45 HST paling sempit. Waktu aplikasi pupuk organik cair juga tidak berpengaruh nyata terhadap luas daun tetapi permukaan daun tanaman yang tidak diberikan pupuk organik cair cenderung lebih luas sedangkan tanaman yang diberikan pupuk organik cair pada 45 HST paling sempit. 
Tabel 2. Luas Daun $\left(\mathrm{cm}^{2}\right)$

\begin{tabular}{cccccc}
\hline Waktu & \multicolumn{4}{c}{ Waktu Aplikasi Pupuk } & \multirow{2}{*}{ Rerata } \\
\cline { 2 - 5 } Benam & Kontrol & $15 \mathrm{HST}$ & $30 \mathrm{HST}$ & $45 \mathrm{HST}$ & \\
\hline Kontrol & $103,9 \mathrm{~b}$ & $120,6 \mathrm{~b}$ & $168,4 \mathrm{~b}$ & $109,4 \mathrm{~b}$ & $125,6 \mathrm{a}$ \\
-7 HST & $143,1 \mathrm{~b}$ & $169,8 \mathrm{~b}$ & $145,3 \mathrm{~b}$ & $178,8 \mathrm{~b}$ & $159,3 \mathrm{a}$ \\
$-14 \mathrm{HST}$ & $540,8 \mathrm{a}$ & $144,4 \mathrm{~b}$ & $147,8 \mathrm{~b}$ & $107,0 \mathrm{~b}$ & $235,0 \mathrm{a}$ \\
$-21 \mathrm{HST}$ & $151,2 \mathrm{~b}$ & $384,2 \mathrm{a}$ & $104,0 \mathrm{~b}$ & $126,8 \mathrm{~b}$ & $191,5 \mathrm{a}$ \\
\hline Rerata & $234,8 \mathrm{a}$ & $204,8 \mathrm{a}$ & $141,4 \mathrm{a}$ & $130,5 \mathrm{a}$ & $(+)$ \\
\hline
\end{tabular}

Keterangan: Angka pada baris dan kolom yang diikuti dengan huruf yang sama tidak berbeda nyata menurut uji DMRT $\alpha 5 \%$. ( + ) : Terjadi interaksi antar faktor

\subsection{Berat Kering Umbi Per Tanaman}

Hasil sidik ragam (Anova) menunjukkan tidak terjadi pengaruh interaksi antara waktu pembenaman pupuk hijau dan aplikasi pupuk organik cair terhadap berat kering umbi per tanaman.

Tabel 3. Berat Kering Umbi Per Tanaman (g)

\begin{tabular}{cccccc}
\hline Waktu & \multicolumn{4}{c}{ Waktu Aplikasi Pupuk } & \multirow{2}{*}{ Rerata } \\
\cline { 2 - 5 } Benam & Kontrol & 15 HST & 30 HST & 45 HST & \\
\hline Kontrol & 4,8 & 3,6 & 3,0 & 3,1 & $3,6 \mathrm{~b}$ \\
-7 HST & 4,7 & 5,6 & 6,9 & 5,3 & $5,6 \mathrm{a}$ \\
-14 HST & 6,4 & 7,1 & 6,3 & 6,5 & $6,6 \mathrm{a}$ \\
-21 HST & 6,0 & 6,6 & 4,6 & 5,3 & $5,6 \mathrm{a}$ \\
\hline Rerata & $5,5 \mathrm{a}$ & $5,7 \mathrm{a}$ & $5,2 \mathrm{a}$ & $5,0 \mathrm{a}$ & $(-)$ \\
\hline Keterangan : & Angka pada baris dan kolom yang diikuti dengan huruf yang sama \\
& tidak berbeda nyata menurut uji DMRT $\alpha$ 5\%. $(-)$ : Tidak terjadi \\
& interaksi antar faktor
\end{tabular}

Umbi setiap bawang putih yang ditanam pada petak dengan pembenaman pupuk hijau secara umum lebih berat dan berbeda nyata dengan berat kering umbi bawang putih yang ditanam pada petak yang tidak dibenamkan pupuk hijau, tetapi penerapan waktu pembenaman pupuk hijau yang berbeda tidak memberikan perberbedaan berat kering umbi setiap tanaman yang nyata walaupun umbi kering setiap tanaman yang ditanam pada petak dengan pembenaman pupuk hijau pada -14 HST cenderung lebih berat.

Waktu aplikasi pupuk organik cair tidak berpengaruh nyata terhadap berat kering umbi per tanaman tetapi data Tabel 3. menunjukkan bahwa umbi setiap tanaman yang diberikan pupuk organik cair pada 15 HST cenderung lebih berat sedangkan umbi setiap tanaman yang diberikan pupuk organik cair pada 45 HST paling ringan.

\subsection{Berat Kering Umbi Per Petak}

Hasil sidik ragam (Anova) menunjukkan tidak terjadi pengaruh interaksi antara waktu pembenaman pupuk hijau dan aplikasi pupuk organik cair terhadap berat kering umbi per petak.

Umbi setiap petak dari bawang putih yang ditanam pada petak dengan pembenaman pupuk hijau secara umum lebih berat dan berbeda nyata dengan berat kering umbi per petak dari bawang putih yang ditanam pada petak yang tidak dibenamkan pupuk hijau, tetapi penerapan waktu pembenaman pupuk hijau yang berbeda tidak memberikan perberbedaan berat kering umbi per petak yang nyata walaupun umbi kering per petak dari tanaman yang ditanam pada petak dengan pembenaman pupuk hijau pada -14 HST cenderung lebih berat.

Tabel 4. Berat Kering Umbi Per Petak (t/ha)

\begin{tabular}{cccccc}
\hline Waktu & \multicolumn{4}{c}{ Waktu Aplikasi Pupuk } & \multirow{2}{*}{ Rerata } \\
\cline { 2 - 5 } Benam & Kontrol & 15 HST & 30 HST & 45 HST & \\
\hline Kontrol & 0,945 & 0,875 & 1,579 & 1,472 & $1,218 \mathrm{~b}$ \\
-7 HST & 4,810 & 3,714 & 4,477 & 4,583 & $4,396 \mathrm{a}$ \\
-14 HST & 4,961 & 5,438 & 4,950 & 4,595 & $4,986 \mathrm{a}$ \\
-21 HST & 4,561 & 4,808 & 4,045 & 5,133 & $4,637 \mathrm{a}$ \\
\hline Rerata & $3,819 \mathrm{a}$ & $3,709 \mathrm{a}$ & $3,763 \mathrm{a}$ & $3,946 \mathrm{a}$ & $(-)$ \\
\hline Keterangan : & Angka pada baris dan kolom yang diikuti dengan huruf & yang sama \\
& tidak berbeda nyata menurut uji DMRT $\alpha$ & $5 \% .(-)$ : Tidak terjadi \\
& interaksi antar faktor
\end{tabular}

Waktu aplikasi pupuk organik cair tidak berpengaruh nyata terhadap berat kering umbi per petak tetapi data Tabel 4. menunjukkan bahwa umbi setiap petak dari tanaman yang diberikan pupuk organik cair pada 45 HST cenderung lebih berat sedangkan umbi setiap petak dari tanaman yang diberikan pupuk organik cair pada 15 HST paling ringan.

\subsection{Berat Siung Tunggal Per Petak}

Hasil sidik ragam (Anova) menunjukkan tidak terjadi pengaruh interaksi antara waktu pembenaman pupuk hijau dan aplikasi pupuk organik cair terhadap berat siung tunggal per petak.

Siung tunggal setiap petak dari bawang putih yang ditanam pada petak dengan pembenaman pupuk hijau secara umum lebih tinggi dan berbeda nyata dengan berat siung tunggal dari bawang putih yang ditanam pada petak yang tidak dibenamkan pupuk hijau, tetapi penerapan waktu pembenaman pupuk hijau yang berbeda tidak memberikan perberbedaan berat siung tunggal yang nyata walaupun siung tunggal per petak dari tanaman yang ditanam pada petak dengan pembenaman pupuk hijau pada -21 HST cenderung lebih berat.

Waktu aplikasi pupuk organik cair tidak berpengaruh nyata terhadap berat siung tunggal per petak tetapi data Tabel 5. menunjukkan bahwa siung tunggal setiap petak dari tanaman yang diberikan pupuk organik cair pada 30 HST cenderung lebih berat sedangkan siung tunggal setiap petak dari tanaman yang diberikan pupuk organik cair pada 15 HST paling ringan.

Tabel 5. Berat Siung Tunggal Per Petak (t/ha)

\begin{tabular}{cccccc}
\hline Waktu & \multicolumn{4}{c}{ Waktu Aplikasi Pupuk } & \multirow{2}{*}{ Rerata } \\
\cline { 2 - 5 } Benam & Kontrol & 15 HST & 30 HST & 45 HST & \\
\hline Kontrol & 0,164 & 0,127 & 0,281 & 0,301 & $0,218 \mathrm{~b}$ \\
-7 HST & 0,285 & 0,444 & 0,481 & 0,337 & $0,387 \mathrm{ab}$ \\
-14 HST & 0,502 & 0,236 & 0,462 & 0,357 & $0,389 \mathrm{ab}$ \\
-21 HST & 0,390 & 0,358 & 0,650 & 0,395 & $0,448 \mathrm{a}$ \\
\hline Rerata & $0,335 \mathrm{a}$ & $0,291 \mathrm{a}$ & $0,469 \mathrm{a}$ & $0,348 \mathrm{a}$ & $(-)$ \\
\hline Keterangan : & $\begin{array}{l}\text { Angka pada baris dan kolom yang diikuti dengan huruf yang sama } \\
\end{array}$ & tidak berbeda nyata menurut uji DMRT $\alpha$ & $5 \% .(-)$ : Tidak terjadi \\
& interaksi antar faktor
\end{tabular}

3.6 Persentase Siung Tunggal Per Petak

Hasil sidik ragam (Anova) menunjukkan tidak terjadi pengaruh interaksi antara waktu pembenaman pupuk hijau dan aplikasi pupuk organik cair terhadap persentase siung tunggal per petak.

Persentase siung tunggal dari bawang putih yang ditanam pada petak dengan pembenaman pupuk hijau secara umum lebih rendah dan berbeda nyata dengan persentase siung tunggal dari bawang putih yang ditanam pada petak yang tidak dibenamkan pupuk hijau dan penerapan waktu pembenaman pupuk hijau yang berbeda tidak memberikan perberbedaan persentase siung tunggal yang nyata walaupun persentase siung tunggal dari tanaman yang ditanam pada petak dengan pembenaman pupuk hijau pada -21 HST cenderung lebih tinggi.

Tabel 6. Persentase Siung Tunggal Per Petak (\%)

\begin{tabular}{cccccc}
\hline Waktu & \multicolumn{4}{c}{ Waktu Aplikasi Pupuk } & \multirow{2}{*}{ Rerata } \\
\cline { 2 - 4 } Benam & Kontrol & 15 HST & 30 HST & 45 HST & \\
\hline Kontrol & 17,6 & 14,5 & 17,7 & 19,2 & $17,2 \mathrm{a}$ \\
-7 HST & 6,2 & 11,9 & 10,8 & 9,0 & $9,5 \mathrm{~b}$ \\
-14 HST & 10,5 & 4,4 & 8,7 & 7,6 & $7,8 \mathrm{~b}$ \\
-21 HST & 11,1 & 7,8 & 17,1 & 7,0 & $10,8 \mathrm{~b}$ \\
\hline Rerata & $11,4 \mathrm{a}$ & $9,6 \mathrm{a}$ & $13,6 \mathrm{a}$ & $10,7 \mathrm{a}$ & $(-)$ \\
\hline Keterangan : & Angka pada baris dan kolom yang diikuti dengan huruf yang sama \\
& tidak berbeda nyata menurut uji DMRT $\alpha$ 5\%. $(-)$ : Tidak terjadi \\
& interaksi antar faktor
\end{tabular}

Waktu aplikasi pupuk organik cair tidak berpengaruh nyata terhadap persentase siung tunggal per petak tetapi data Tabel 6. menunjukkan bahwa persentase siung tunggal setiap petak dari tanaman yang diberikan pupuk organik cair pada 30 HST cenderung lebih tinggi sedangkan persentase siung tunggal setiap petak dari tanaman yang diberikan pupuk organik cair pada 15 HST paling rendah.

\subsection{Berat Kering Berangkasan}

Hasil sidik ragam (Anova) menunjukkan tidak terjadi pengaruh interaksi antara waktu pembenaman pupuk hijau dan aplikasi pupuk organik cair terhadap berat kering berangkasan.

Waktu pembenaman pupuk hijau tidak berpengaruh nyata terhadap berat kering berangkasan tetapi data Tabel 7. menunjukkan bahwa berangkasan kering dari tanaman yang ditanam pada petak dengan pembenaman pupuk hijau pada -14 HST cenderung lebih berat sedangkan berangkasan kering dari tanaman yang ditanam pada petak dengan pembenaman pupuk hijau pada -30 HST paling ringan. Waktu aplikasi pupuk organik cair juga tidak berpengaruh nyata terhadap berat kering berangkasan tetapi berangkasang kering dari tanaman yang diberikan pupuk organik cair pada 45 HST cenderung lebih berat sedangkan berangkasan kering dari tanaman yang diberikan pupuk organik cair pada 30 HST paling ringan.

Tabel 7. Berat Kering Berangkasan (t/ha)

\begin{tabular}{cccccc}
\hline Waktu & \multicolumn{4}{c}{ Waktu Aplikasi Pupuk } & \multirow{2}{*}{ Rerata } \\
\cline { 2 - 5 } Benam & Kontrol & 15 HST & 30 HST & 45 HST & \\
\hline Kontrol & 1,074 & 1,152 & 1,060 & 1,234 & $1,130 \mathrm{a}$ \\
-7 HST & 0,995 & 1,150 & 0,929 & 1,394 & $1,117 \mathrm{a}$ \\
-14 HST & 1,341 & 1,595 & 1,283 & 1,919 & $1,534 \mathrm{a}$ \\
-21 HST & 1,152 & 1,165 & 1,257 & 1,794 & $1,342 \mathrm{a}$ \\
\hline Rerata & $1,140 \mathrm{a}$ & $1,265 \mathrm{a}$ & $1,132 \mathrm{a}$ & $1,585 \mathrm{a}$ & $(-)$ \\
\hline Keterangan : & Angka pada baris dan kolom yang diikuti dengan huruf yang sama \\
& tidak berbeda nyata menurut uji DMRT $\alpha$ & 5\%. $(-)$ : Tidak terjadi \\
& interaksi antar faktor
\end{tabular}

3.8 Indeks Panen

Hasil sidik ragam (Anova) menunjukkan tidak terjadi pengaruh interaksi antara waktu pembenaman pupuk hijau dan aplikasi pupuk organik cair terhadap indeks panen. 
Indeks panen dari bawang putih yang ditanam pada petak dengan pembenaman pupuk hijau secara umum lebih tinggi dan berbeda nyata dengan indeks panen dari bawang putih yang ditanam pada petak yang tidak dibenamkan pupuk hijau, tetapi penerapan waktu pembenaman pupuk hijau yang berbeda tidak memberikan perberbedaan indeks panen yang nyata walaupun indeks panen dari tanaman yang ditanam pada petak dengan pembenaman pupuk hijau pada -7 HST cenderung lebih tinggi.

Waktu aplikasi pupuk organik cair tidak berpengaruh nyata terhadap indeks panen tetapi data Tabel 8. menunjukkan bahwa indeks panen dari tanaman yang diberikan pupuk organik cair pada 30 HST cenderung lebih tinggi sedangkan indeks panen dari tanaman yang diberikan pupuk organik cair pada 15 HST paling rendah.

Tabel 8. Indeks Panen (\%)

\begin{tabular}{cccccc}
\hline Waktu & \multicolumn{4}{c}{ Waktu Aplikasi Pupuk } & \multirow{2}{*}{ Rerata } \\
\cline { 2 - 5 } Benam & Kontrol & 15 HST & 30 HST & 45 HST & \\
\hline Kontrol & 47,2 & 44,1 & 59,6 & 55,8 & $51,7 \mathrm{~b}$ \\
-7 HST & 82,3 & 76,4 & 82,7 & 75,5 & $79,2 \mathrm{a}$ \\
-14 HST & 78,9 & 77,4 & 79,3 & 71,2 & $76,7 \mathrm{a}$ \\
-21 HST & 77,3 & 79,8 & 75,9 & 73,1 & $76,5 \mathrm{a}$ \\
\hline Rerata & $71,4 \mathrm{a}$ & $69,4 \mathrm{a}$ & $74,4 \mathrm{a}$ & $68,9 \mathrm{a}$ & $(-)$ \\
\hline Keterangan : & Angka pada baris dan kolom yang diikuti dengan huruf & yang sama \\
& tidak berbeda nyata menurut uji DMRT $\alpha$ & $5 \% .(-)$ : Tidak terjadi \\
& interaksi antar faktor
\end{tabular}

\subsection{Pembahasan}

Pembenaman pupuk hijau pada -14 HST memberikan pertumbuhan bawang putih siung tunggal berupa tanaman yang paling tinggi saat pengamatan 75 HST dengan ukuran permukaan daun yang paling luas sehingga berangkasan kering juga paling berat. Selain pertumbuhan vegetatif, hasil yang dicapai juga lebih baik berupa umbi setiap tanaman maupun setiap petak yang lebih berat, siung tunggal yang dihasilkan tidak terlalu berat tetapi tidak berbeda nyata dengan berat siung tunggal yang paling berat yang dihasilkan oleh bawang putih yang ditanam pada petak yang dibenamkan pupuk hijau saat -21 HST.

Aplikasi pupuk organik cair pada 45 HST memberikan hasil panen berupa berat kering umbi per petak yang paling berat walaupun umbi setiap tanamannya paling ringan dengan pertumbuhan vegetatif berupa tanaman yang lebih pendek dan permukaan daun yang paling sempit tetapi berangkasan keringnya paling berat. Siung tunggal yang dihasilkan juga tidak terlalu berat.

\section{Simpulan}

Berdasarkan hasil dan pembahasan yang dilakukan maka dapat disimpulkan beberapa hal sebagai berikut:

a. Interaksi antara waktu pembenaman pupuk hijau dan aplikasi pupuk organik cair hanya terjadi terhadap luas daun.

b. Secara umum pembenaman pembenaman pupuk hijau berpengaruh nyata terhadap suhu tanah 50 HST, tinggi tanaman setiap waktu pengamatan, berat kering umbi per tanaman maupun per petak, berat siung tunggal per petak, persentase siung tunggal per petak dan indeks panen tetapi penerapan waktu pembenaman pupuk hijau yang berbeda hanya berpengaruh nyata terhadap tinggi tanaman 25 HST, sedangkan waktu aplikasi pupuk organik cair hanya berpengaruh nyata terhadap suhu tanah 50 HST.

c. Pembenaman pupuk hijau pada -14 HST memberikan hasil panen tertinggi yakni 4,99 t/ha. Aplikasi pupuk organik cair pada 45 HST memberikan hasil panen tertinggi yaitu 3,95 t/ha.

Pustaka

Anantyo, D.T., 2009. Efek Minyak Atsiri dari Bawang Putih (Allium sativum) terhadap Persentase Jumlah Neutrofil Tikus Wistar yang diberi diet kuning telur. Medical faculty.

BPS Kab. TTU, 2011. Timor Tengah Utara dalam Angka. Badan Pusat Statistik Kabupaten TTU, Kefamenanu.

BPS Kab. TTU, 2007. Timor Tengah Utara dalam Angka. Badan Pusat Statistik Kabupaten TTU, Kefamenanu.

BPS RI, 2014. Statistik Indonesia. Badan Pusat Statistik Republik Indonesia, Jakarta.

Gomez, K.A., Gomez, A.A., 1984. Statistical Procedures for Agricultural Research. John Wiley \& Sons.

Hilman, Y., 1994. Pengaruh cara aplikasi fosfat dan kombinasi pupuk nitrogen, fosfat dan kalium terhadap pertumbuhan dan hasil bawang putih yang ditanam dengan sistem complongan. Bul. Penelit. Hortik.

Parman, S., 2007. Pengaruh Pemberian Pupuk Organik Cair terhadap Pertumbuhan dan Produksi Kentang (Solanum tuberosum L.). J. Anat. Fisiol. 15.

Rahmi, A., Jumiati, 2007. Pengaruh Konsentrasi dan Waktu Penyemprotan Pupuk Organik Cair Super ACI terhadap Pertumbuhan dan Hasil Jagung Manis. Agritrop 26

Santoso, B., 1988. Bawang Putih. Kanisius, Yogyakarta. 